\title{
Papers
}

\section{Factors Related To Annual Fund-Raising Contributions from Individual Donors to NCAA Division I-A Institutions}

Received (in revised form): July 11, 2005

\section{Douglas E. Wells}

Douglas E. Wells is Assistant Professor in the Department of Physical Education at the United States Air Force Academy. Dr. Wells' research interests are collegiate fund raising, sport marketing, and sponsorship.

\section{Richard M. Southall}

Richard M. Southall is Assistant Professor in Sport and Leisure Management at the University of Memphis. Dr. Southall specializes in legal issues in collegiate sport, sport marketing research, and ethical issues in sport management.

\section{David Stotlar}

David K. Stotlar is Professor of Sport Management at the University of Northern Colorado. Dr. Stotlar's research interests are sport marketing and sponsorship, Olympic sports, and sport management.

\section{Daniel J. Mundfrom}

Daniel J. Mundfrom is Professor and Chair of the Department of Applied Statistics and Research Methods at the University of Northern Colorado. Dr. Mundfrom's research interests include statistical methods, multivariate statistics, teaching statistics, and missing data manipulation.

\section{Abstract}

The purpose of this study was to identify selected factors related to annual fundraising program contributions at National Collegiate Athletic Association (NCAA)

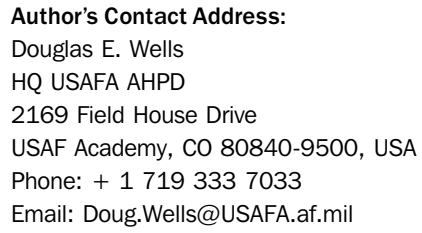

Division I-A (D I-A) institutions and develop an equation for estimating an annual fund-raising goal. Based on a review of the literature, 15 potential predictor variables were selected and a survey instrument was developed to collect data on annual fund-raising contributions from individual donors and the selected factors. Surveys were mailed to the Director of Development for each Division I-A football institution $(n=114)$. Seventy useable questionnaires were returned, resulting in a 65.4 percent 
response rate. Multiple linear regression and Pearson product-moment correlation statistics were used to analyze the data. Based on the study's findings, a predictive equation was developed that can be utilized by D I-A athletic administrators in setting their annual fund-raising goal. The final model resulted in a statistically significant model that accounted for 78.1 percent of the variation in annual contributions. Five of the 15 selected predictor variables were determined to be significant in accounting for the variation in annual fund-raising contributions.

\section{Keywords:}

capital campaign, annual fund raising, NCAA D I-A, atbletic department giving

\section{Introduction}

Fund raising has become an increasingly important source of revenue for college athletic programs. ${ }^{1}$ It has been reported that if institutional support was excluded, over 50 percent of NCAA D I-A athletic programs would fail to turn a profit. $^{2}$ Escalating costs associated with coaches' salaries, increased number of women's sports teams, tuition cost increases, Title IX compliance, coupled with decreased public sector funding, have contributed to an increased reliance on fund raising as an important external revenue source. ${ }^{3}$ Fund-raising contributions are currently the second largest source of revenue for NCAA D I-A programs, accounting for 17 percent of total revenues. ${ }^{4}$ Despite these financial trends, there has been limited research regarding collegiate athletic fund raising. In addition, there is little empirical data about private donations to intercollegiate athletic departments. ${ }^{5}$ This knowledge gap raises several questions: (1) Does a successful football team lead to more contributions? (2) Does the increased staff size and experience increase contributions? (3) Do certain demographic characteristics influence the amount of money that can be raised? This study analyzed how well 15 potential predicator variables explained variation in private monetary contributions to athletic departments' annual fund-raising programs and developed a practical, predictive model that directors of development can utilize in estimating annual contribution goals.

\section{Literature Review}

The topic of fund raising has received minimal scholarly attention and in many cases the research has been of poor quality. ${ }^{6}$ The study of college athletics fund raising has received even less attention and the robustness of the findings has also been criticized. ${ }^{7}$ As many athletic departments have treated contribution data as proprietary information, relatively few studies have been conducted. ${ }^{8}$ In general, research has not determined the impact of successful athletic teams on annual fund-raising contributions to universities and their athletic departments. 9

The results from studies that utilized contribution data from D I-A athletic programs are questionable, because all but one of the studies utilized data reported from a single source-a newspaper article. ${ }^{10}$ In addition the data set in question only included programs defined as "big-time" college athletic programs. Snyder and Hoover collected data on annual contributions at D I-A institutions, ${ }^{11}$ but failed to report their sample size and response rate, making it impossible to assess their finding's validity and reliability, and their results were published in a nonreferred source.

A review of college athletics fundraising research reveals three primary research foci: (1) investigating donor 
motivations, (2) studying the "spillover effect," and (3) analyzing factors that affect annual contributions to athletic departments' fund-raising programs.

First, researchers have addressed donor motivations, focusing on athletic-donor motivations and the development of donor-assessment instruments. ${ }^{12}$

Secondly, researchers have examined the "spillover effect" associated with successful athletic programs. These studies have primarily focused on determining what variables have an effect on giving to a university's annual fund-raising program, with an emphasis on determining the impact of various athletic success variables. ${ }^{13}$ The researchers in three of these studies determined that athletic success, depending on the variable used to measure it, does have an effect on annual contributions. ${ }^{14}$ However, the researchers in the remaining four studies found no significant relationship between successful athletic programs and contributions to the university. ${ }^{15}$

The third focus of researchers examining college athletic fund raising has been an attempt to determine what factors affect annual contributions to athletic departments' fund-raising programs. These researchers have been primarily interested in investigating successful athletic performance-primarily at the D I-A leveland its hypothesized relationship with increased contributions. Coughlin and Erekson and Sigelman and Bookheimer both utilized a data set from an article in the Omaha World-Herald. ${ }^{16}$ Both research teams pointed out that they could not be certain exactly what type of contributions were included in the reported figures. Sigelman and Bookheimer utilized simple correlation statistics to determine that football success, as measured by a fouryear weighted average, and a traditionalbased culture had a significant positive relationship with contributions to the athletic department. In addition, they conducted multiple linear regression (MLR) analysis, utilizing a model that included numerous variables hypothesized to affect annual fund-raising contributions. Football success was the only variable that remained in the model and had a positive significant relationship with increasing contributions. ${ }^{17}$ Coughlin and Erekson developed 10 different variations of contribution models. The model with the highest explanatory power was based on economic theory, $\mathrm{R}^{2}=0.58$. Results indicated that football attendance, Atlantic Coast Conference affiliation, bowl appearance, state population, basketball win/loss percentage, and professional competition all had a significant effect on athletic contributions. All had a positive regression sign with the exception of professional competition. ${ }^{18}$ Snyder and Hoover conducted a similar study of D I-A institutions, but focused on institutional factors. ${ }^{19}$ Findings indicated that win/loss percentage did not have an impact on contributions, but type of school, the number of years a full-time fund-raising position had been established, and number of part-time fund raisers employed at the institution all had a positive significant effect on annual contributions. The last study to be discussed involved a qualitative analysis $(\mathrm{n}=10)$ of D I-A programs. Hall and Mahony, among other factors, determined that the status of the institution (public vs. private), win/loss percentage, state of the local economy and level of competition (ie, other colleges and professional sports) were all environmental factors that impacted annual fund-raising programs at D I-A institutions. $^{20}$

In summary, the literature review pertaining to athletic department 
contributions reveals conflicting results and few empirical studies focused on giving to athletic departments. Although the statistical analysis and theoretical frameworks were satisfactory, the results are not. This points to a void in the athletic fund-raising research and this study was an attempt to start filling that void. Daughtrey and Stotlar examined the relationship between giving to both the athletic department and the university to determine if winning a national football championship at the D I-AA, D II, and D III levels increased contributions. ${ }^{21}$ Overall the results indicated that there was a positive relationship with giving to D II and D III athletic departments, while only D III universities enjoyed an increase in university donations following a championship year. The remainder of the studies, with the exception of Hall and Mahony's qualitative analysis, ${ }^{22}$ examined Division I-A programs through the development of empirical models.

\section{Methodology}

This study used a Pearson productmoment correlation matrix and MLR to answer the following research questions:

1. What factors will affect contributions to NCAA Division I-A athletic departments' annual fund-raising program?

2. What relationships exist between the factors of annual fund-raising contributions?

3. Can a useful predictive model be developed that will provide an estimate of annual fund-raising contributions to NCAA Division I-A athletic departments' annual fund-raising program?

A survey instrument was developed to collect descriptive data utilizing eight "potential" predictor variables which would then be combined with seven additional predictor variables collected from secondary sources. These variables would be used to analyze the relationship between the predictor variables and the criterion variable. This study's criterion variable was monetary contributions (eg, cash, check, or charge) made by private individuals during the FY 2000 annual fund-raising program. The predictor variables were selected after a review of the literature and were divided into four categories. The first category of predictor variables was identified as institutional characteristics. Institutional characteristics included the institution's total number of living alumni and the type of institution (public or private). The second category of predictor variables was identified as demographic characteristics. Demographic characteristics included state population, state median per capita personal income, and the number of schools that participated in college athletics in the state. The third category was defined as organizational fund-raising characteristics and included the following variables: (1) total number of years the institution had designated a full-time fund-raising position; (2) continuous number of years the institution had conducted an annual fund-raising program; (3) the Director of Development's total number of years' experience in the field of fund raising; (4) the total number of part-time paid staff members that worked on the athletic department's annual fund-raising program; (5) the size of the athletic department's prospective donor list; and (6) the total number of volunteers utilized during the athletic department's annual fund-raising program. The fourth category included predictor variables associated with institutional atbletic success characteristics. These variables included the following: (1) 
accumulated percentage of stadium capacity for football attendance; (2) season football ticket sales; (3) previous year football win/loss percentage; and (4) appearance in a bowl game at the end of 1999-2000 football season.

The population and subsequent sample for this study was defined as all NCAA Division I-A institutions that participated in the 1999 football season. There were a total of 114 member institutions that fit this description. The survey was designed to be completed by the athletic department's Director of Development. A mailed questionnaire was the chosen survey method and a basic survey procedure that included four mailings was implemented over approximately a onemonth period. ${ }^{23}$

\section{Results}

A total of 80 institutions out of 114 responded to the questionnaire. Three institutions indicated that they did not conduct an fiscal year 2000 annual fundraising program and were removed from the study. Four institutions noted that their annual fund-raising programs were conducted by the university's development office and they were also removed from the study. Three respondents provided incomplete surveys that could not be used. The final sample size was reduced to 107 with 70 completed and useable surveys, resulting in a response rate of 65.4 percent. Eight of the 11 conferences and the grouping of "independents" were represented by at least 57 percent of the membership. The Big East (25 percent), Big Ten (40 percent), and Conference USA (37.5 percent) were the only conferences whose representation fell below the 57 percent level. Private schools comprised 11.5 percent of the sample as compared with a 15 percent representation in the population, and schools attending bowl games comprised 44 percent of the sample as compared with a 40 percent representation in the population.

Mean contributions for FY 2000 annual program were $\$ 4,216,503$. The Pearson product-moment correlation matrix indicated that football season ticket sales was most highly correlated with annual contributions, $r=0.823$. This makes inherent sense as most D I-A football programs "utilize a two-part tariff for the sale of football tickets." 24 In this tariff system, patrons pay for a season ticket and then make a contribution. The size of the contribution determines seat location and the "amount" of other benefits associated with the contribution. The second, third, and fourth variables moderately correlated with annual contributions were "number of living alumni”" $(r=0.617)$, "accumulated season football attendance" ( $r=0.501)$, and "appearance in a bowl game" $(r=0.454)$.

All 15 predictor variables were used to run an MLR model. The full model resulted in an $R^{2}$ of 0.797 with an $F$-value of 14.10 and a resulting $p$-value of less than 0.0001 . The adjusted $R^{2}$, a more conservative estimate, was 0.741 .

Regression assumptions were also tested for the model and determined to meet the necessary criteria for analysis. In an effort to develop a more parsimonious model, variables that contributed least to explaining variation in the model were removed one at a time. The final model resulted in five retained variables (all statistically significant at a 0.05 alpha level) with an $R^{2}$ of 0.781 and an adjusted $R^{2}$ of 0.764 . The retained predictor variables explained 76.4 percent of the variation in annual contributions. The $F$-value of 45.65 was also statistically significant at a 0.05 alpha level. All of the final predictor variables (see Table 1) carried a positive regression coefficient, 
Table 1: Final multiple linear regression model $(n=70)$

\begin{tabular}{lcrc}
\hline Variable & Regression coefficient & $\boldsymbol{S E}$ & $\boldsymbol{t}$ \\
\hline Intercept & $-1,864,868.31$ & $573,196.15$ & $-3.25^{*}$ \\
Number of years' experience & $77,024.43$ & $32,507.13$ & $2.37^{*}$ \\
Number of years' full-time position & $46,452.91$ & $15,786.32$ & $2.94^{*}$ \\
1999 season ticket sales & 102.12 & 12.75 & $8.01^{*}$ \\
Number of living alumni & 6.24 & 2.95 & $2.12^{*}$ \\
Size of prospective donor list & 39.18 & 14.52 & $2.70^{*}$ \\
\hline
\end{tabular}

$F(5,69)=45.65, " p<0.05, R^{2}=0.781 ;$ Adjusted $R^{2}=0.764$.

indicating they had a positive relationship with increasing annual contributions.

A new finding from this study is that the Director of Development's fundraising experience (in years) was determined to have a positive significant effect on annual fund raising. In addition, this study's finding of a significant relationship for the number of years a full-time fund raising position has been designated supports Snyder and Hoover's research. ${ }^{25}$ Similar to Hall and Mahony's findings that seating priority plays a significant role in determining annual contributions, ${ }^{26}$ the sale of season tickets had the most significant relationship with annual fund-raising contributions. Two additional unique findings from this study are that the number of living institutional alumni and size of an athletic department's prospective donor list are both significant predictors at increasing annual contributions. The variables for number of years of fund raising experience, alumni, and prospective donor list should be further examined as predictor variables in future studies of annual fund-raising contributions. The explanatory power of the model exceeded previous models and indicates that the answer to the third research question is, "Yes, a useful model can be developed to predict annual fundraising contributions."

\section{Conclusion}

Intercollegiate athletic fund raising is an increasingly important revenue stream for athletic departments. This study's results offer practical guidance to athletic administrators on what factors have the most significant impact on increasing annual contributions. Quantitative data analysis reveals that season ticket sales and the number of years' fund raising experience of the department's Director of Development play a crucial role in increasing annual contributions. This "truism" among intercollegiate athletic fund raisers is supported by this study's findings.

This study did not find football win/ loss percentage to be a significant factor in the MLR model (ie it explained little variation in annual contributions).

However, the results of the correlation matrix indicated that there was a significant positive relationship between the athletic success factor of bowl-game appearance and annual contributions $(r=0.454, p<0.0001)$. It is important to note that you cannot appear in a bowl without a winning season. The correlation between bowl-game appearance and attendance was also determined to be significant $(r=0.586, p<0.0001)$. In addition, the correlation between win/loss percentage and attendance was also significant $(r=0.463, p<0.0001)$, 
indicating that winning programs are moderately correlated to increasing attendance.

At the D II level, winning has been determined to be a statistically significant factor in increasing attendance. ${ }^{27}$ As winning is correlated with increasing season ticket sales $(r=0.362, p=0.0021)$ and season ticket sales are highly correlated with increased attendance $(r=0.621, p<0.0001)$, it appears that although winning has not been found to be significantly related to annual contributions, its impact on bowl-game appearance and attendance via increased season ticket sales does play a major role, reflecting a "spillover effect" to annual contributions. The importance of such relationships should not be ignored.

In addition, repeated winning seasons and bowl-game appearances would most likely increase the magnitude of the purported relationships and points to an area of further research. Having a "single" winning or losing season, prior to the annual fund raising fiscal year does not have a significant impact on annual contributions, but Sigelman and Bookheimer (1983) have determined that "multiple" winning or losing seasons have a significant effect on athletic department contributions. ${ }^{28}$ This study's findings, along with Sigelman and Bookheimer's research, indicate that the win/loss variable should be studied further, focusing on examining the longterm effects of progressive winning or losing seasons on annual contributions.

The results of this study support two previous research findings. However, the results fail to support several of the previous findings, as many variables determined to be significant in previous studies were not determined to be statistically significant. This supports the need for further research of athletic department fund raising. This study is only the third reported attempt at successfully collecting "specific" athletic fund-raising contribution data from D I-A athletic programs. In addition it is the first known quantitative analysis of annual contributions from individual donors. The moderate success of the data collection effort indicates that athletic departments may be willing to share this type of information in the future.

Therefore, more efforts should be made to collect data of this nature. Through viewing and analyzing the raw data, it is apparent that future research should be directed toward analyzing annual athletic fund-raising programs at the micro level. It appears that the proximal environments facing each athletic department or conference are different enough that quantitative analysis at the macro level may not be the best analysis strategy. ${ }^{29}$ For example, in all likelihood Duke University's fund raising-success is not driven by factors associated with a winning football program. Future analysis should focus on examining fund-raising contributions to athletic departments in more homogeneous groups. In addition, research of D I-AA, D II, and D III athletic fund-raising programs is almost nonexistent. ${ }^{30}$ Future qualitative research in this field would add to the literature. The study of intercollegiate athletic fund raising is absolutely "wide open" and it appears that athletic department development officers are more willing to share contribution data now than in the past. Now all that needs to be done is the hard, unglamorous work of collecting and analyzing the data.

\section{References}

1. J. S. Hall and D. F. Mahony (1997), "Factors affecting methods used by annual giving programs: A qualitative study of NCAA Division I athletic departments," Sport Marketing Quarterly, 6, 3, pp. 
21-30; D. R. Howard and J. L. Crompton (1995), Financing Sport, Fitness Information Technology, Inc., Morgantown, WV; W. F. Stier Jr. (1992), "Understanding fundraising in sport: The conceptual approach," Sport Marketing Quarterly, 1, pp. $41-6$.

2. D. L. Fulks (2000), Revenues and Expenses of Division I and II Intercollegiate Atbletics Programs: Financial Trends and Relationships - 2000, The National Collegiate Athletic Association, Overland Park, KS, p. 35.

3. Howard and Crompton (1995), Financing Sport, op. cit.; J. Snyder and S. Hoover (1986), "Athletic fund raising: Examining key variables," Athletic Administration, 21, September, pp. 15-16.

4. Fulks (2000), op. cit., p. 35.

5. B. Goff (2000), "Effects of university athletics on the university: A review and extension of empirical assessment," Journal of Sport Management, 14, pp. 85104; M. E. Verner, J. B. Hecht, and A. G. Fansler (1998), "Validating an instrument to assess the motivation of athletics donors," Journal of Sport Management, 12, pp. 123-37.

6. K. S. Kelly (1991), Fund Raising and Public Relations: A Critical Analysis, Lawrence Erlbaum Associates, Hillsdale, NJ.

7. Goff (2000), op. cit.; Hall and Mahony (1997), op. cit.; A. Padilla and J. L. Boucher (1988), "On the economics of intercollegiate athletic programs," Journal of Sport and Social Issues, 11-12, pp. 61-73; R. Tsiotsou (1998), "Motivations for donation to athletic programs," The Cyber-Journal of Sport Marketing, 2, 2, pp. 1-13. Retrieved September 2005 from http://www.ausport.gov.au/fulltext/1998/cjsm/ v2n2/tsiotsou $22 . h t m$.

8. L. Sigelman and S. Bookheimer (1983), "Is it whether you win or lose? Monetary contributions to big-time college athletic programs," Social Science Quarterly, 64, pp. 347-59.

9. C. Daughtrey and D. Stotlar (2000), "Donations: Are they affected by a football championship?" Sport Marketing Quarterly, 9, 4, pp. 185-93.

10. Padilla and Boucher (1988), op. cit.

11. Snyder and Hoover (1986), op. cit.

12. C. Ostlund and J. D. Brown (1985, March), "Predicting potential donors for intercollegiate athletics," Atbletic Business, March, pp. 30-1; Tsiotsou (1998), op. cit.; Verner et al. (1998), op. cit.

13. R. A. Baade and J. O. Sundberg (1996), "Fourth down and gold to go? Assessing the link between athletics and alumni giving," Social Science Quarterly, 77, 4, pp. 789-803; G. Brooker and T. D. Klastorin (1981), "To the victors belong the spoils? College athletics and alumni giving," Social Science Quarterly, 62, pp. 744-50; J. F. Gaski and M. J. Etzel (1984), "Collegiate athletic success and alumni generosity:
Dispelling the myth," Social Behavior and Personality, 12, 1, pp. 29-38. P. W. Grimes and G. A. Chressanthis (1994), "Alumni contributions to academics: The role of intercollegiate sports and NCAA sanctions," American Journal Economics and Sociology, 53, 1, pp. 27-40; A. C. Marts (1934),

"College football and college endowment," School and Society, 40, pp. 14-15; A. L. Sack and C. Watkins (1985), "Winning and giving," in D. Chu, J. O. Segrave, and B. J. Becker (eds.), Sport and Higher. Education, Human Kinetics Publishers, Champaign, IL, pp. 299-306; L. Sigelman and R. Carter (1979), "Win one for the giver? Alumni giving and big-time college sports," Social Science Quarterly, 60, September, pp. 284-93.

14. Baade and Sundberg (1996), op. cit.; Brooker and Klastorin (1981), op. cit.; Grimes and Chressanthis (1994), op. cit.

15 Gaski and Etzel (1984), op. cit.; Marts (1934), op. cit.; Sack and Watkins (1985), op. cit.; Sigelman and Carter (1979), op. cit.

16. C. C. Coughlin and H. O. Erekson (1984), “An examination of contributions to support intercollegiate athletics," Southern Economic Journal, 66, pp. 180-95; C. C. Coughlin and H. O. Erekson (1985), "Contributions to intercollegiate athletic programs: Further evidence," Social Science Quarterly, 66, pp. 194-202; Sigelman and Bookheimer (1983), op. cit.

17. Sigelman and Bookheimer (1983), op. cit.

18. Coughlin and Erekson (1984), op. cit.; Coughlin and Erekson (1985), op. cit.

19. Snyder and Hoover (1986), op. cit.

20. Hall and Mahony (1997), op. cit.

21. Daughtrey and Stotlar (2000), op. cit.

22. Hall and Mahony (1997), op. cit.

23. P. Salant and D. A. Dillman (1994), How To Conduct Your Own Survey, John Wiley \& Sons, Inc., New York.

24. Coughlin and Erekson (1984), op. cit., p. 182.

25. Snyder and Hoover (1986), op. cit.

26. Hall and Mahony (1997), op. cit.

27. T. D. DeSchriver (1999), "Factors affecting spectator attendance at NCAA Division II football games," International Sports Journal, 3, 2, pp. 55-65; D. E. Wells, R. M. Southall, and H. H. Peng (2000), "An analysis of factors related to attendance at Division II football games," Sport Marketing Quarterly, 9, 4, pp. 203-10.

28. Sigelman and Bookheimer (1983), "Is it whether you win or lose?" op. cit.

29. P. Chelladurai (2001), Managing Organizations For Sport and Physical Activity: A Systems Perspective. Holcomb Hathaway, Scottsdale, AZ.

30. Daughtrey and Stotlar (2000), “Donations," op. cit. 